\title{
Interactive comment on "An instrument for in-situ measurement of total ozone reactivity" by Roberto Sommariva et al.
}

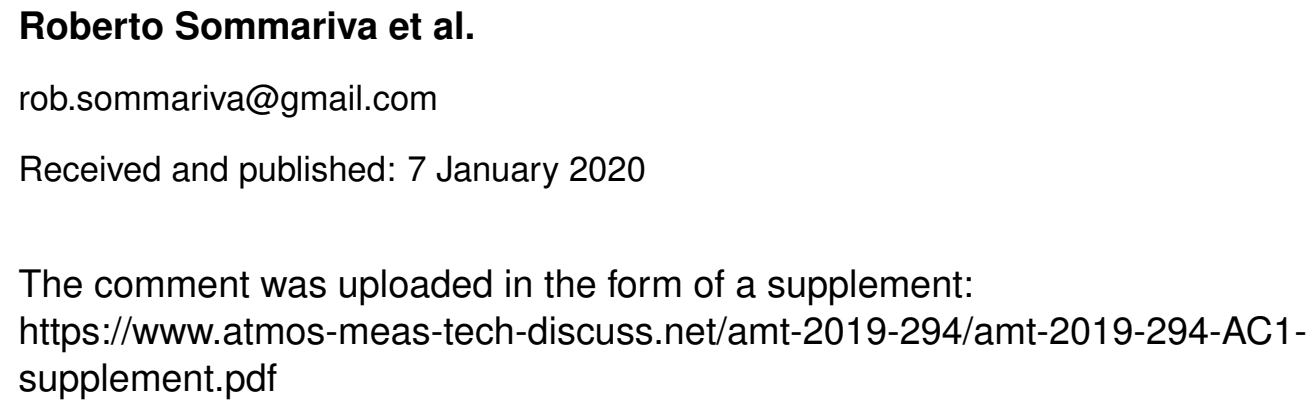

Interactive comment on Atmos. Meas. Tech. Discuss., doi:10.5194/amt-2019-294, 2019. 